\title{
The phylogenetic position of Aglaodorum Schott (Araceae - Aroideae - Aglaonemateae)
}

\author{
Hong Thien Van ${ }^{1}$, Nga Nguyen-Phi ${ }^{2} \&$ Hong Truong Luu ${ }^{3}$ \\ ${ }^{1}$ Institute of Biotechnology and Food technology, Industrial University of Ho Chi Minh City, 12 Nguyen \\ Van Bao, Go Vap District, Ho Chi Minh City, Vietnam; vanhongthien@iuh.edu.vn \\ 2 Department of Ecology and Evolutionary Biology, University of Science, Vietnam National University \\ HCMC, 227 Nguyen Van Cu, District 5, Ho Chi Minh City, Vietnam \\ ${ }^{3}$ Southern Institute of Ecology, Vietnam Academy of Science and Technology, 1 Mac Dinh Chi, District \\ 1, Ho Chi Minh City, Vietnam
}

\begin{abstract}
Van H. T., Nguyen-Phi N. \& Luu H. T. (2020): The phylogenetic position of Aglaodorum Schott (Araceae - Aroideae - Aglaonemateae). Thaiszia - J. Bot. 30 (1): 093-101.

Abstract: Analysis of chloroplast DNA sequences (trnL intron and trnLtrnF intergenic spacer) of the helophytic colony-forming Aglaodorum griffithii (Schott) Schott and other representative species of Araceae supported its placement within Aglaonema Schott. It is therefore proposed that Aglaodorum Schott should be recognised as a generic synonym of Aglaonema.
\end{abstract}

Keywords: Araceae, Aglaonema griffithii, Aglaodorum griffithii, trnL, trnL-trnF.

\section{Introduction}

Aglaonema griffithii Schott was first described by Schott (1856) from Peninsular Malaysia. Two years later, he realized that this species have some differences from other species of Aglaonema Schott (see below) and so he created a new genus, Aglaodorum Schott, and transferred Aglaonema griffithii Schott into it (Schott 1858). Schott's view was not always followed, however. For example, Teijsmann \& Binnendijk (1863) described Aglaonema palustre Teijsm. \& Binn., which is a synonym of Aglaodorum griffithii (Schott) Schott (Boyce et al. 2012), from Sumatra, and 
Hooker (1883: 981) and Ridley (1925: 100) both treated Aglaodorum as a synonym of Aglaonema. Nevertheless, Engler, the great authority on Aroids after Schott, maintained Aglaodorum as a genus allied to but separate from Aglaonema (Engler 1915: 34), and since then Aglaodorum has been accepted as a monotypic genus the sole species of which is distributed in southern Cambodia, southern Vietnam, south and west through Peninsular Malaysia and Sumatra, and east to northern and western Borneo (Mayo et al. 1997; Boyce et al. 2012).

The morphology of Aglaodorum griffithii is known to be extremely similar to that of Aglaonema, especially in the structure of spathe, male and female spadix, ovary, stigma, ovule and leaf blade (Nicolson 1969). However, there are some notable differences: Aglaodorum griffithii is traditionally distinguished from the species of Aglaonema by having one whorl of pistillate flowers (versus several whorls) and peduncles of $40-50 \mathrm{~cm}$ in length (versus the much shorter ones). Moreover, Aglaodorum griffithii has large green spongy fruits adapted to floating dispersal, spongy rhizomes, peduncles and petioles apparently adapted to growing on soft mud and in water, and is helophytic in open conditions, while Aglaonema species are terrestrial on tropical forest floor, almost always in shade and the fruits are red or more rarely pink and bird-dispersed (Schott 1858; Nicolson 1969; Mayo et al. 1997; Boyce et al. 2012). However, these morphological characteristics are known individually to vary greatly within other genera of Araceae. Arrangement of pistillate flowers in only one whorl is known in Aglaonema costatum N.E.Br. (Ridley 1925) and thus it is not a distinct characteristic for Aglaodorum. We therefore set about investigating whether these genera really can be maintained distinct.

Here, we analyse molecular data of eleven taxa of Araceae and one Acoraceae in order to determine the phylogenetic affinity of Aglaodorum griffithii. We also evaluated taxonomic usefulness of morphological characters that have traditionally placed Aglaodorum griffithii within Aglaonema.

\section{Material and Methods}

Eleven taxa of Araceae and one Acoraceae used in this study were collected from southern regions of Vietnam (Tab. 1), including three species of Aglaonema. Each taxon had one sample except for Aglaodorum griffithii with three samples from the Mekong Delta provinces of Tien Giang (H. T. Van 103A), Ben Tre (H. T. Van 103B) and Long An (H. T. Van 103C). All voucher specimens are stored at SGN Herbarium. The $\operatorname{trnL}$ and trnL-trnF sequences obtained were submitted to GenBank and the assigned accession numbers are listed in Tab. 1.

Total genomic DNA was extracted from fresh leaf tissues using a Genomic DNA Purification Mini Kit (Thermo, USA). The trnL intron and trnL-trnF IGS chloroplast DNA region were amplified by polymerase chain reaction (PCR). List of primers is shown in Tab. 2. The PCR reactions were performed in an Eppendorf Mastercycler Gradient using a volume of $25 \mu \mathrm{l}$ reaction mixture: $12.5 \mu \mathrm{l}$ go taq green master mix (Promega, USA), $1.25 \mu$ l of each forward and reverse primers $(10 \mu \mathrm{M}), 9.5 \mu$ l ultrapure water and $0.5 \mu$ I DNA template (25ng). PCR cycles consisted of an initial denaturation 
Tab. 1 Specimens of eleven Araceae and one Acoraceae species used in this study.

\begin{tabular}{|c|c|c|}
\hline $\begin{array}{c}\text { Studied } \\
\text { specimens } \\
\text { (SGN) }\end{array}$ & Species & $\begin{array}{c}\text { Accession numbers } \\
\text { (trnL intron/trnL-trnF } \\
\text { IGS) }\end{array}$ \\
\hline H.T.Van 99 & Acorus calamus L. & MN844006/MN844022 \\
\hline H.T.Van 103A & Aglaodorum griffithii (Schott) Schott & MN844014/MN844028 \\
\hline H.T.Van 103B & Aglaodorum griffithii (Schott) Schott & MN844015/MN844029 \\
\hline H.T.Van 103C & Aglaodorum griffithii (Schott) Schott & MN844016/MN844030 \\
\hline H.T.Van 23 & Aglaonema cochinchinense Engl. & MN844007/MN844023 \\
\hline H.T.Van 91 & Aglaonema simplex (Blume) Blume & MN844012/MN844026 \\
\hline H.T.Van 116 & $\begin{array}{l}\text { Aglaonema costatum form. immaculatum } \\
\text { (Ridl.) Nicolson }\end{array}$ & MN844008/MN844020 \\
\hline H.T.Van 79 & Arisaema roxburghii Kunth & MN844011/MN844025 \\
\hline H.T.Van 18 & Colocasia esculenta (L.) Schott & MN844013/MN844027 \\
\hline H.T.Van 62 & Alocasia macrorrhizos (L.) G.Don & MN844009/MN844024 \\
\hline H.T.Van 03 & $\begin{array}{l}\text { Amorphophallus paeoniifolius (Dennst.) } \\
\text { Nicolson }\end{array}$ & MN844010/MN844021 \\
\hline H.T.Van 102 & Pistia stratiotes L. & MN844018/MN844032 \\
\hline H.T.Van 61 & Pothos chinensis (Raf.) Merr. & MN844017/MN844031 \\
\hline H.T.Van 42 & Typhonium trilobatum (L.) Schott & MN844019/MN844033 \\
\hline
\end{tabular}

for 5 min at $95^{\circ} \mathrm{C} ; 35 \mathrm{cycles}$ of denaturation $\left(1 \mathrm{~min}\right.$ at $\left.94^{\circ} \mathrm{C}\right)$, annealing $\left(1 \mathrm{~min}\right.$ at $\left.50^{\circ} \mathrm{C}\right)$ and extension $\left(1: 30 \mathrm{~min}\right.$ at $\left.72^{\circ} \mathrm{C}\right)$; and a final extension at $72^{\circ} \mathrm{C}$ for $10 \mathrm{~min}$. The $\mathrm{PCR}$ products were visualized on $1.5 \%$ agarose gel and sent for purification and direct sequencing at Nam Khoa Biotek Company Ltd (Vietnam) by using ABI $3130 \mathrm{XL}$ Sequencer.

For multiple alignments, the ClustalW (Thompson et al. 1994) was used to recognize the homology between sequences. Phylogenetic analysis was carried out with the software PAUP* 4.0a146 (Swofford 2002) and MrBayes (Ronquist \& Huelsenbeck 2003) using the maximum parsimony and Bayesian methods with Acorus calamus L. (Acoraceae) as outgroup, following Cabrera et al. (2008); Cusimano et al. (2011); Nauheimer et al. (2012). The maximum parsimony trees were calculated based on chloroplast sequence data with gaps treated as missing data and heuristic search algorithms (Nei \& Kumar 2000) with the following parameters: 1000 random addition sequence replicates, tree bisection reconnection (TBR) branch swapping, 10 parsimonious trees held after each replicate (Yulita et al. 2005; Harrison \& Langdale 2006). All characters were equally weighted and treated as unordered (Fitch 1971). The fit of characters to the trees was also tested by calculating the consistency index $(\mathrm{Cl})$, the retention index $(\mathrm{RI})$ and the rescaled consistency index (RC) (Kluge \& Farris 1969; Farris 1989). The Bayesian Markov-chain Monte Carlo (MCMC) was constructed on the software MrBayes (Ronquist \& Huelsenbeck 2003). The algorithm used in this study was a two million-generation MCMC with one cold and three heated chains, which was set to start from random trees and sampled every $100^{\text {th }}$ generation. The standard deviation of split frequencies was used as an index to assess the convergence, the values of which 
Tab. 2 Primers used in the present study. $\left({ }^{*}\right)$ direction of primer $F$ (forward), $\mathbf{R}$ (reverse).

\begin{tabular}{cccc}
\hline Primers $\left(^{*}\right)$ & Regions & Sequence (5'-3') & References \\
\hline A $(\mathrm{F})$ & trnL intron & CGAAATCGGTAGACGCTACG & \\
$\mathrm{B}(\mathrm{R})$ & trnL intron & GGGGATAGAGGGACTTGAAC & \multirow{2}{*}{ Taberlet et al. (1991) } \\
$\mathrm{C}(\mathrm{F})$ & trnL-trnF IGS & GGTTCAAGTCCCTCTATCCC & \\
$\mathrm{D}(\mathrm{R})$ & $\operatorname{trnL-trnF~IGS}$ & ATTTGAACTGGTGACACGAG & \\
\hline
\end{tabular}

Tab. 3 Mean pairwise genetic distances between ingroup species based on the combined data set of trnL intron and trnL-trnF IGS.

\begin{tabular}{lccccccccccc}
\hline & 1 & 2 & 3 & 4 & 5 & 6 & 7 & 8 & 9 & 10 & 11 \\
\hline 1. Aglaonema costatum & & & & & & & & & & & \\
2. Aglaodorum griffithii & 0.003 & & & & & & & & & \\
3. Aglaonema simplex & 0.006 & 0.009 & & & & & & & & \\
4. Aglaonema cochinchinense & 0.017 & 0.020 & 0.020 & & & & & & & \\
5. Pothos chinensis & 0.065 & 0.068 & 0.068 & 0.080 & & & & & & \\
6. Amorphophallus & 0.046 & 0.049 & 0.049 & 0.061 & 0.087 & & & & & \\
paeoniifolius & 0.061 & 0.065 & 0.065 & 0.073 & 0.105 & 0.051 & & & & \\
7. Alocasia macrorrhizos & 0.078 & 0.082 & 0.082 & 0.087 & 0.127 & 0.068 & 0.053 & & & \\
8. Pistia stratiotes & 0.072 & 0.075 & 0.075 & 0.075 & 0.109 & 0.058 & 0.035 & 0.061 & & \\
9. Arisaema roxburghii & 0.059 & 0.063 & 0.062 & 0.071 & 0.104 & 0.046 & 0.038 & 0.054 & 0.046 & \\
10. Typhonium trilobatum & 0.056 & 0.060 & 0.059 & 0.068 & 0.096 & 0.043 & 0.028 & 0.046 & 0.038 & 0.030 \\
11. Colocasia esculenta & & & & & & & & & & \\
\hline
\end{tabular}

reaching $<0.005$ are considered as a good convergence. The initial $10 \%$ of trees were discarded as burnin while the remaining of them were used to build up $50 \%$ majorityrule consensus trees. The pairwise genetic distances (Kimura 1980) were calculated using the software MEGA6 (Tamura et al. 2013).

\section{Results and discussion}

The length of combined data set (trnL intron and trnL-trnF IGS) ranged from 760 to $892 \mathrm{bp}$. The entire aligned length of two regions is $976 \mathrm{bp}$. The mean pairwise genetic distances between the genera based on the combined data set are shown in Tab. 3 with the lowest value belonging to Aglaonema and Aglaodorum. Accordingly, the genetic distances between Aglaodorum griffithii and Aglaonema costatum $\mathrm{f}$. immaculatum (Ridl.) Nicolson, A. simplex (Blume) Blume and A. cochinchinense Engl. were $0.003,0.009$ and 0.020 , respectively. The phylogenetic analysis of the combined data set resulted in one of the most-parsimonious tree (length: 471 steps, $\mathrm{Cl}: 0.82$, RI: 0.79, RC: 0.71 ) and the Bayesian tree (Fig. 1 \& 2). Both analyses grouped Aglaodorum and Aglaonema in one clade with maximum bootstrap value (100\%). All specimens of Aglaodrum griffithii (103A, 103B, 103C), Aglaonema simplex and A. costatum f. immaculatum are grouped together and nested in Aglaonema clade with Aglaonema cochinchinense as sister. 
Our phylogenetic analyses are consistent with previous studies on the generic groups, indicating the very close affinity of Aglaonema and Aglaodorum, both belonging to the tribe Aglaonemateae (Mayo et al. 1997; Cabrera et al. 2008; Cusimano et al. 2011; Nauheimer et al. 2012). However, these studies only used one species of Aglaonema and Aglaodorum griffithii to construct the phylogenies while three species of Aglaonema were analysed in our study. All individuals of Aglaodorum griffithii collected from three different provinces in southern Vietnam are clearly nested within Aglaonema in both the maximum parsimony or Bayesian trees. Therefore, we propose that the monotypic genus Aglaodorum should be reduced to the synonymy of Aglaonema and the name Aglaonema griffithii be resurrected.

As an aside, an interesting parallel is found in another Asian aroid group, Homalomena Schott, which is an almost entirely forest floor genus with one species being a colony-forming helophyte that grows in open conditions (often with Aglaodorum) - the Bornean H. expedita A.Hay \& Hersc. (Hay \& Herscovitch 2002), the position of which within Homalomena Schott, despite distinctive reproductive features (Wong et al. 2011) is also supported by molecular studies (Wong et al. 2013).

\section{Taxonomic treatment}

Aglaonema griffithii Schott, Syn. Aroid. 123, 1856; Hook. f., Fl. Brit. India 6: 528, 1893; Ridl., Mat. Fl. Malay Penins. 19, 1907; Ridl., Fl. Malay Penins. 5: 100, 1925; Aglaodorum griffithii (Schott) Schott, Gen. Aroid. 58: 58, 1858; Schott, Prodr. Syst. Aroid.: 306, 1860; Engl. in A DC. \& C DC, Monogr. Phan. 2: 443, 1879; Benth. \& Hook. f., Gen. PI. 3(2): 981, 1883; Engl. in Engl. \& Prantl, Nat. Pflanzenfam. 2(3): 135, 1889; Engl. in Engl., Pflanzenr. IV, 23Dc (Heft 64): 34, Fig. 16, 1915; Nicolson, Smiths., Contr. Bot. 1: 36, 1969; Mayo, Bogner \& Boyce, Gen. Arac. 225: pl. 78, 123A, 1997; Phamh., Illustr. Fl. Vietn. 3: 351, fig. 9114, 2000; V.D. Nguyen, Arac. Vietn.: 78, 2006; P.C. Boyce et al., FI. Thail. 11: 110, 2012; - Type: MALAYSIA, Malacca, without date (ca. 1842), W. Griffith 5991 (K, holo \& iso, seen on-line).

Evergreen, helophytic colony-forming herbs, $40-60 \mathrm{~cm}$ high. Stem rhizomatous, spongy, $2.0-2.5 \mathrm{~cm}$ in diameter. Leaves few, each subtended by cataphylls; petioles terete, spongy, dark green, $30-40 \mathrm{~cm}$ long, ca. $1.5 \mathrm{~cm}$ in diameter; sheath very short; leaf blade oblanceolate, thick, 20-30 cm long, 12-15 cm wide, dark green above, pale green under side; midrib thick, impressed adaxially and prominent abaxially, lateral veins diverging from the midrib and toward margin. Inflorescence solitary; peduncle terete, spongy, dark green, $30-50 \mathrm{~cm}$ long, ca. $1 \mathrm{~cm}$ in diameter; spathe oblong, cuspidate, not differentiated into a lower tube and upper limb, green, 7-8 $\mathrm{cm}$ long, ca. $1 \mathrm{~cm}$ in diameter; spadix stipitate, $6-7 \mathrm{~cm}$ long; female part with a single whorl of flowers, loosely arranged; ovaries pale green or pale yellow, 1-locular with 1 basal ovule; style absent; stigma yellow, concave at centre, $4 \mathrm{~mm}$ long, 2-2.5 $\mathrm{mm}$ wide; male part cylindrical, thecae opening apically by elongate pore. Infructescence 
ultimately declinate; fruit obovoid to ellipsoid, pale green, $3-4 \mathrm{~cm}$ long, $1-2 \mathrm{~cm}$ wide, floating (Fig. 3).

Distribution: Southern Vietnam, Thailand, Cambodia, south and west through Peninsular Malaysia and Sumatra, and East to North Borneo.

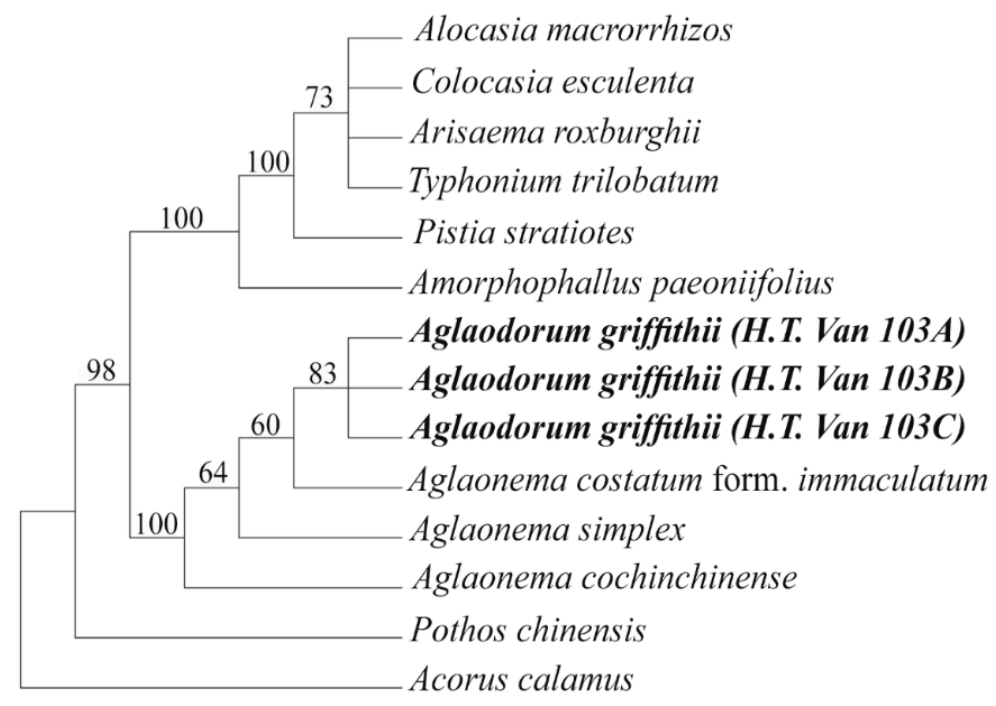

Fig. 1 One of most-parsimonious tree obtained based on the combined data set of trnL intron and trnL-trnF IGS. Gaps treated as missing data. The bootstrap values of $50 \%$ or more are shown above the nodes. Tree length $=471$ steps, $\mathrm{Cl}=0.82, \mathrm{RI}=$ 0.79 , and $\mathrm{RC}=0.71$.

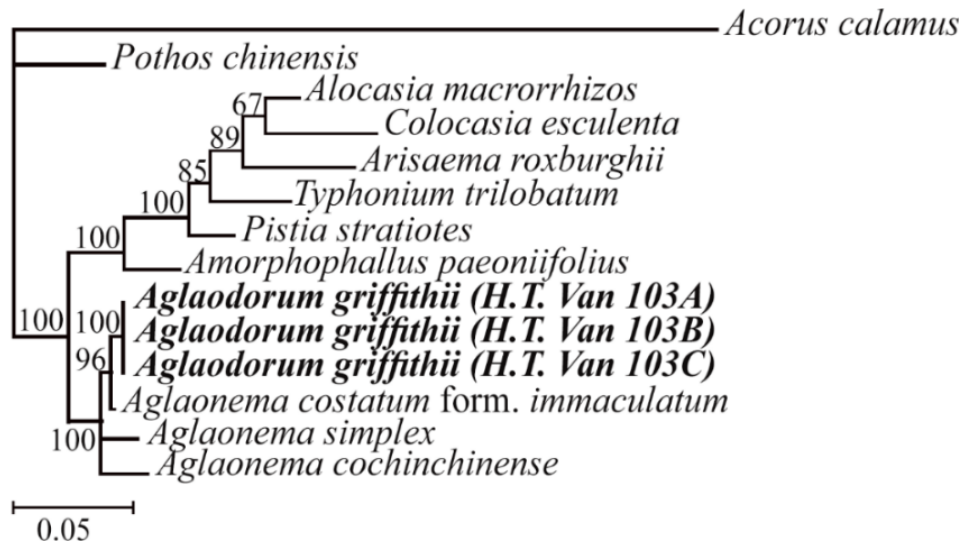

Fig. 2 Bayesian tree obtained from the combined data set of trnL intron and trnLtrnF IGS. The bootstrap values of $50 \%$ or higher are shown above the nodes. 

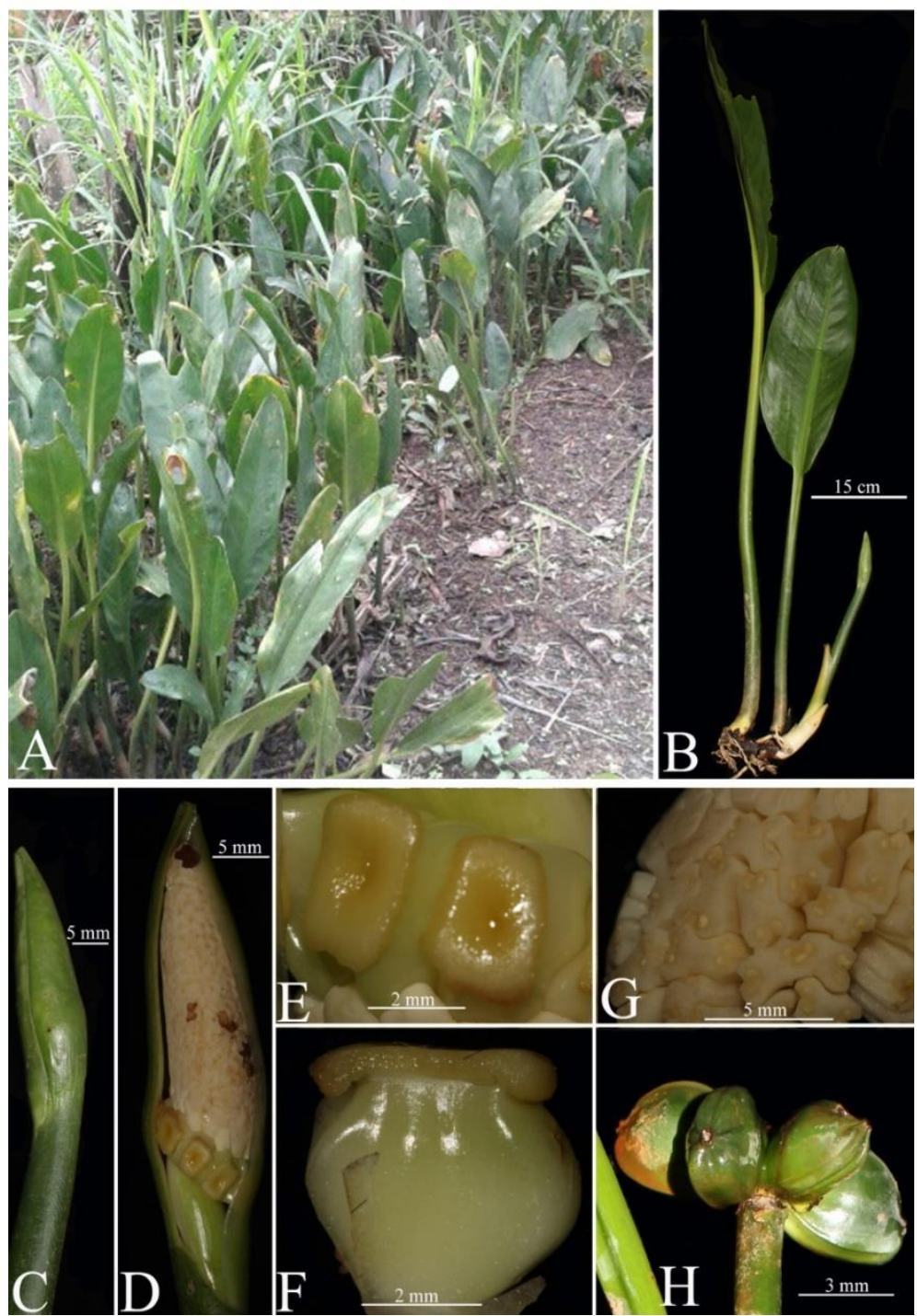

Fig. 3 Aglaonema griffithii Schott. (A) habiit and habitat, (B) petiole, leaf blade and inflorescence, (C) spathe, (D) spadix, (E) stigma, (F) ovary, (G) stamens, (H) fruits.

Studied specimens: Vietnam, Tien Giang Province, Cho Gao District, $10^{\circ} 19^{\prime} 17^{\prime \prime} \mathrm{N}$; $106^{\circ} 29^{\prime} 08^{\prime \prime} \mathrm{E}, 10$ m elevation, 20 July 2015, collected by Hong Thien Van, H. T. Van 103A (SGN!); Ben Tre Province, Tam Phuoc District, 10¹7'700”N; 106²1'16"E, $15 \mathrm{~m}$ elevation, 01 August 2015; collected by Hong Thien Van, H. T. Van 103B (SGN!); Long An Province, Ben Luc District, 1041'124"N; 106 33'972"E, 12 m elevation, 05 August 2015, collected by Hong Thien Van, H. T. Van 103C (SGN!); Saigon (Ho Chi Minh City), 20 May 1921, Poilane 520 (P, seen images); Malaysia, 1856, Griffith 5991 (K, seen images); Sai Gon City, Vietnam, 20 May 1921, Poilane 520 (P, seen images); Malaysia, Malacca, Griffith 5991 (K, seen images). 


\section{References}

Boyce P. C., Sookchaloem D., Hetterscheid W. L. A., Gusman G., Jacobsen N., Idei T. \& Nguyen V. D. (2012): Araceae. - Flora of Thailand 11: 101-321.

Cabrera L. I., Salazar G. A., Chase M. W., Mayo S. J., Bogner, J. \& Dávila P. (2008): Phylogenetic relationships of aroids and duckweeds (Araceae) inferred from coding and noncoding plastid DNA. - Am. J. Bot. 95/9: 1153-1165. doi.org/10.3732/ajb.0800073

Cusimano N., Bogner J., Mayo S. J., Boyce P. C., Wong S. Y., Hesse M., Hetterscheid W. L. A., Keating R. C. \& French J. C. (2011): Relationships within the Araceae: comparison of morphological patterns with molecular phylogenies. - Am. J. Bot. 98/4: 654-668. doi.org/10.3732/ajb.1000158

Engler A. (1915): Anubiadeae, Aglaonemateae, Dieffenbachieae, Zantedeschieae, Typhonodoreae, Peltandreae. - Das Pflanzenreich IV.23Dc (Heft 64): 1-78.

Farris J. S. (1989): The retention index and the rescaled consistency index. - Cladistics 5/4: 417-419. doi.org/10.1111/j.1096-0031.1989.tb00573.x

Fitch W. M. (1971): Towards defining the course of evolution: minimum change for a species tree topology. - Syst. Zool. 20/4: 406-416. DOI: 10.2307/2412116

Harrison C. J. \& Langdale J. A. (2006): A step by step guide to phylogeny reconstruction. Plant J. 45/4: 561-572. DOI: 10.1111/j.1365-313X.2005.02611.x

Hay A. \& Herscovitch C. (2002): Two remarkable new West Malesian Homalomena (Araceae) Species. - Gard. Bull. Singapore 54: 171-178.

Hooker J. D. (1883): Aroideae. - In: Bentham G. \& Hooker J. D. Genera Plantarum 3: 9551000.

Kimura M. (1980): A simple method for estimating evolutionary rates of base substitutions through comparative studies of nucleotide sequences. - J. Mol. Evol. 16: 111-120. doi.org/10.1007/BF01731581

Kluge A. \& Farris J. (1969): Quantitative phyletics and the evolution of anurans. - Syst. Zool. 18/1: 1-32. DOI: 10.2307/2412407

Mayo S. J., Bogner, J. \& Boyce, P. C. (1997): The Genera of Araceae. - Royal Botanic Gardens, Kew.

Nauheimer L., Dirk M. \& Susanne S. R. (2012): Global history of the ancient monocot family Araceae inferred with models accounting for past continental positions and previous ranges based on fossils. - New Phytologist 195/4: 938-950. DOI: 10.1111/j.1469-8137.

Nei M. \& Kumar S. (2000): Molecular Evolution and Phylogenetics. - Oxford University Press, New York, 333p.

Nicolson D. H. (1969): A revision of the genus Aglaonema (Araceae). - Smithsonian Contr. Bot. 1: 36. https://doi.org/10.5962/bhl.title.123257

Ridley H. N. (1925): Aroideae. - The Flora of the Malay Peninsula 5: 84-131.

Ronquist F. \& Huelsenbeck J. P. (2003): MrBayes 3: bayesian phylogenetic inference under mixed models. - Bioinformatics 19/12: 1572-1574.

doi.org/10.1093/bioinformatics/btg180

Schott H. W. (1856): Synopsis Aroidearum. - Vindobonae.

Schott H. W. (1858): Genera Aroidearum. - Vindobonae.

Swofford D. L. (2002): PAUP*. Phylogenetic Analysis Using Parsimony (*and Other Methods). Version 4.0 Beta. - Sinauer Associates, Sunderland, Massachusetts. DOI: 10.1111/j.00143820.2002.tb00191.x 
Taberlet P., Gielly L., Patou G. \& Bouvet J. (1991): Universal primers for amplification of three non-coding regions of chloroplast DNA. - Plant Mol. Biol. 17: 1105-1109. doi.org/10.1007/BF00037152

Tamura K., Stecher G., Peterson D., Filipski A. \& Kumar S. (2013): MEGA6: Molecular Evolutionary Genetics Analysis Version 6.0. - Mol. Biol. Evol. 30/12: 2725-2729. doi: 10.1093/molbev/mst197

Teijsmann J. E. \& Binnendijk S. (1863): Plantea novae in Horto Bogoriensi cultae. - Tijdschrift voor Nederlandsch-Indiae 25: 399-428.

Thompson D. J., Higgins D. G. \& Gibson T. J. (1994): CLUSTAL W: improving the sensitivity of progressive multiple sequence alignment through sequence weighting, position-specific gap penalties and weight matrix choice. - Nucleic Acids Res 22/22: 4673-4680. DOI: 10.1093/nar/22.22.4673

Yulita K. S., Bayer R. J. \& West J. G. (2005): Molecular study of Hopea and Shorea (Dipterocarpaceae): Evidence from the trnL-trnF and internal transcribed spacer regions. - Plant Spec. Biol. 20/3: 167-182. doi.org/10.1111/j.1442-1984.2005.00136.x

Wong S. Y., Boyce P. C. \& Ahmad F. B. (2011): Studies on Homalomeneae (Araceae) of Borneo III: The helophytic Homalomena of Sunda. - Gardens' Bull. Singapore 62/2: 313-327.

Wong S. Y., Tan P. J., Ng K. K., Othman A. S., Lee H. B., Ahmad F. B. \& Boyce P. C. (2013): Phylogeny of Asian Homalomena (Araceae) based on the ITS region combined with morphological and chemical data. - Systematic Botany 38/3: 589-599. doi.org/10.1600/036364413X670430 